\author{
ANNA MIŚKOWIEC \\ Wydział Teologiczny Katolickiego Uniwersytetu Lubelskiego Jana Pawła II
}

\title{
Znaczenie kultury w dziele ewangelizacji
}

Kiedy zbliżamy się do innego narodu, innej kultury lub innej religii, naszym pierwszym zadaniem powinno być zdjęcie butów, ponieważ miejsce, ku któremu zdążamy jest święte. Jeżeli tego nie zrobimy, narażamy się na to, że możemy podeptać marzenia innych ludzi, co gorzej, możemy zapomnieć o tym, że Bóg był tam przed nami i On tam także będzie, gdy my opuścimy to miejsce ${ }^{1}$.

Anonim

Każdy człowiek rodzi się i wzrasta w konkretnym narodzie, kulturze i społeczeństwie, gdzie spotyka i w jakiś sposób przyjmuje za swój określony sposób percepcji świata, system wartości i przekonań religijnych. Można powiedzieć, że kultura jest częścią naszej tożsamości i bogactwa duchowego. Dlatego, aby w spotkaniu z drugim człowiekiem zapewnić wzajemny szacunek i ducha dialogu, należy uwzględnić kulturowy kontekst, z którego on pochodzi. Jak poucza nas Konstytucja duszpasterska o Kościele Soboru Watykańskiego II, Gaudium et spes, także Bóg dostosował się do poziomu człowieka i „przemawiał do swego ludu stosownie do stanu kultury właściwego różnym epokom"2, zanim ostatecznie objawił się w swym wcielonym Synu, Jezusie Chrystusie. Przez wcielenie Syn Boży zjednoczył się w jakiś sposób z każdym człowiekiem, a Duch Święty wszystkim ofiarowuje możliwość dojścia do uczestniczenia w tej tajemnicy ${ }^{3}$. Również Kościół w ciągu wieków posługiwał się dorobkiem różnych kultur, aby orędzie zbawcze docierało do wszystkich narodów, przenikało całe życie chrześcijanina i by jak najlepiej wyrażało

\footnotetext{
${ }^{1}$ C. Ezeam, Formation multiculturelle, „Spiritus” 190 (2008), s. 37.

${ }^{2}$ Sobór Watykański II, Konstytucja duszpasterska o Kościele w świecie współczesnym Gaudium et spes (dalej Gaudium et spes), Poznań 2002, nr 58.

${ }^{3}$ Por. Jan Paweł II, Redemptoris missio, nr 6.
} 
się w liturgii ${ }^{4}$. Pomiędzy orędziem zbawienia a kulturą ludzką istnieją więc wielorakie powiązania, na które głosiciel Ewangelii powinien zwrócić szczególną uwagę.

Kościół w swej pracy ewangelizacyjnej wychodzi ku człowiekowi, który „jest pierwszą i podstawową drogą Kościoła"5, i pragnie go spotkać w całej prawdzie jego istnienia: bycia osobowego, wspólnotowego i społecznego, aby skierować jego wzrok ku tajemnicy Chrystusa ${ }^{6}$. Jak Chrystus wcielił się w konkretną kulturę swoich czasów, tak Kościół, wchodząc w kontakt z nowymi sytuacjami, wciela Ewangelię w różne kultury, uznając także za swoje to, co w nich dobre i szlachetne. Rzeczywistość spotkania Ewangelii i kultury dokonuje się więc przez odkrywanie „zarodków słowa"7 - semina verbi obecnych w dziedzictwie kulturowym narodów i społeczeństw, aby w ten sposób móc kształtować autentyczny chrześcijański obraz ludzkości i by wspólnie tworzyć kulturę bardziej ludzką .

W swej pracy ewangelizacyjno-misyjnej Kościół, pochylając się nad człowiekiem w całym jego bogactwie kulturowym, jest szczerze zatroskany, by głoszone słowo było właściwie zrozumiane i przyjęte. Stąd podczas prób szukania coraz lepszych rozwiązań konieczny staje się dialog teologii z kulturą przy zachowaniu integralności głoszonego orędzia oraz w poszanowaniu wolności sumienia i integralnego rozwoju człowieka. Wcielanie Ewangelii w kultury pozostanie zawsze długotrwałym procesem, natomiast $\mathrm{z}$ drugiej strony chrześcijańskie przeżywanie wiary nigdy nie może się do końca wyrazić w jakiejkolwiek formie kulturowej, stąd inkulturacja będzie polegała na nieustannym poszukiwaniu nowych, adekwatnych form wyrazu, uwzględniających sposoby życia i myślenia właściwe dla danego czasu i kręgu kulturowego.

We współczesnej nauce funkcjonuje wiele sposobów rozumienia kultury. Kościół katolicki w dokumentach również określił swoje stanowisko w tej kwestii. Pojęcie kultury jest kategorią opisującą ważne aspekty życia ludzkie-

\footnotetext{
${ }^{4}$ Por. Gaudium et spes, dz. cyt., nr 58.

${ }^{5}$ Jan Paweł II, Redemptor hominis, nr 14.

${ }^{6}$ Por. Jan Paweł II, Redemptoris missio, dz. cyt., nr 4.

7 „Aby sami mogli owocnie dawać to świadectwo o Chrystusie, niech okazują tym ludziom szacunek i miłość, niech uznają siebie za członków wspólnoty ludzi, wśród których żyją, i niech uczestniczą w życiu kulturalnym i społecznym przez różne kontakty i powiązania życia ludzkiego; niech zaznajamiają się z ich tradycjami narodowymi i religijnymi; niech z radością i szacunkiem odnajdują ukryte w nich ziarna słowa" - Sobór Watykański II, Dekret o misyjnej działalności Kościoła Ad gentes (dalej Ad gentes), Poznań 2002, nr 11.

${ }^{8}$ Konstytucja dogmatyczna o Kościele Soboru Watykańskiego II, Lumen gentium, w następujący sposób interpretuje istotę działalności Kościoła w świecie: „wszelkie dobro, jakie zostało zasiane w sercach i umysłach ludzi, we własnych obrzędach i kulturach narodów, nie tylko nie ginie, lecz zostaje uleczone, wyniesione i dopełnione na chwałę Boga, aby zawstydzić szatana, a uszczęśliwić człowieka" - Sobór Watykański II, Konstytucja dogmatyczna o Kościele Lumen gentium, Poznań 2002, nr 17.
} 
go, wobec czego jego zgłębianie jest nieodzowne dla działań ewangelizacyjno-misyjnych. W związku z tym rodzi się pytanie, na ile współczesne sposoby definiowania kultury są przydatne w lepszym rozumieniu zadań chrześcijan i wypełnianiu ich w codziennym życiu oraz w realizacji projektów ewangelizacyjno-misyjnych Kościoła.

\section{Wokół pojęcia kultury - etymologia i antropologiczne ujęcia kultury}

Kultura jest pojęciem, które dotyczy wszystkich ludzi i wszystkich społeczności oraz wyraża sposób, w jaki człowiek przystosowuje się do świata, rozwija własne człowieczeństwo oraz kształtuje swoją tożsamość ${ }^{9}$. Etymologicznie termin kultura wywodzi się od łacińskiego czasownika colere i oznacza „uprawiać, dbać, pielęgnować, kształcić”. Pierwotnie termin ten wiązał się z uprawą roli i hodowlą zwierząt oraz oznaczał takie przekształcenie środowiska naturalnego, by było bardziej przydatne i użyteczne dla człowieka ${ }^{10}$. Kultura, przeciwstawiana naturze, jest pojęciem związanym z działaniami i wytworami człowieka ${ }^{11}$. Tak więc to, co jest pielęgnacją i uprawą natury przez człowieka, jest różne od tego, „co się rodzi samo, wyłącznie dzięki działaniu natury" ${ }^{12}$. To przeciwstawienie pojęć bierze się stąd, że tworzenie natury można określić jako spontaniczne rodzenie (słowo natura pochodzi od łacińskiego nascere - 'rodzić się'), natomiast w dziedzinie kultury mamy do czynienia $\mathrm{z}$ intencjonalnym działaniem człowieka - twórczością ${ }^{13}$.

W I w. p.n.e. termin kultura zyskał nowe metaforyczne znaczenie ${ }^{14}$. Marcus Tullius Cicero jako pierwszy użył terminu kultura w rozumieniu bardzo bliskim współczesnemu ujęciu. W Rozmowach tuskulańskich (Tusculanae disputationes) posłużył się sformułowaniem cultura animi - 'kultura ducha' ('uprawa umysłu'), aby określić w ten sposób pierwszą w literaturze koncepcję filozofii ${ }^{15}$. Cyceron wnioskował, że człowiek przez „uprawę ducha”, przez „uprawę umysłu” doszedł do wielu osiągnięć takich, jak: zakładanie miast, organizacja struktur społecznych jednoczących ludzi przez mieszkanie na

\footnotetext{
${ }^{9}$ Por. A. Pietrzak, Uzasadnienie inkulturacji we wspótczesnej teologii, „Roczniki Teologiczne” 54 (2007), z. 9, s. 6.

${ }^{10}$ Por. A. Kłosowska, Kultura, w: Encyklopedia kultury polskiej XX wieku. Pojęcia i problemy wiedzy o kulturze, red. A. Kłosowska, Wrocław 1991, s. 17.

${ }^{11}$ Por. F. König, K. Waldenfels, Kultura/Kultury, w: ciż, Leksykon religii, Warszawa 1997, s. 209.

${ }^{12}$ R. Jaszczuk, Ewangelizacja kultur i inkulturacja Ewangelii, Warszawa 2012, s. 55.

${ }^{13}$ Por. K. Wojtyła, Rozważania o istocie czlowieka, Kraków 1999, s. 28.

${ }^{14}$ Por. F. König, K. Waldenfels, Kultura/Kultury, dz. cyt., s. 209.

${ }^{15}$ Por. R. Jaszczuk, Ewangelizacja kultur..., dz. cyt., s. 55. Por. http://pl.wikipedia.org/wiki/ Kultura, [dostęp 20.10.2014].
} 
jednym terytorium, zawieranie małżeństw oraz posługiwanie się jednym językiem i pismem. Bardzo dużą rolę w kształtowaniu zarówno jednostki, jak i całych społeczeństw odegrało wynalezienie i respektowanie praw, dobrych obyczajów i ładu ${ }^{16}$.

Od okresu Odrodzenia terminem kultura, który był używany zamiennie z pojęciem cywilizacja, zaczęto określać całokształt czynności ludzkich, podkreślając harmonijny rozwój wszystkich uzdolnień fizycznych i duchowych człowieka ${ }^{17}$.

Warto nadmienić, że na gruncie polskim, chociaż należeliśmy do kręgu cywilizacyjnego, gdzie znane było Cycerońskie ujęcie kultury, przez długi czas termin ten nie występował w literaturze. Raczej posługiwano się - na wzór francuski - pojęciem cywilizacja. Termin kultura w swym szerokim i nowoczesnym ujęciu pojawił się po raz pierwszy w dziele Joachima Lelewela $W y$ kład dziejów powszechnych i swym zasięgiem obejmował religię, moralność, obyczaje, organizację społeczną, pracę fizyczną i umysłową, różne dziedziny nauki i sztuki ${ }^{18}$.

Człowiek jako twórca kultury ma także odniesienie do rzeczywistości wyższej, przekraczającej otaczający go świat. Jest on istotą poszukującą sensu życia i same wynalazki ludzkich rąk i umysłu nie zaspokoją jego aspiracji ani tęsknot. Potrzebuje jeszcze innego wymiaru, by móc zrozumieć samego siebie, potrzebuje odniesienia do Boga i religii. Istnieje ścisły związek między kulturą a religią. Arystoteles już ponad dwa tysiące lat temu określił, że religia jest jedną z czterech dziedzin kultury. Według niego kultura to doskonalenie człowieka (paidagogia), co dokonuje się w dziedzinach:

- umysłu - doskonalenie poznania (wiedza, nauka),

- woli - doskonalenie postępowania (etyka, moralność),

- duszy - odniesienie do Bóstwa - religia, kult,

- władz sprawczych - sztuka (estetyka) ${ }^{19}$.

Nie można więc religii wykluczyć z dziedziny kultury, co jest dążeniem niektórych prądów myślowych czy założeń ideologicznych, bo religia należy do istoty kultury, a nawet jest jej sercem. Religia, chociaż jest sprawą najbardziej osobistą, nie przestaje być sprawą społeczną. Natomiast religię i kulturę należy odróżnić, a nie rozdzielać, gdyż nie można ich traktować na tej samej płaszczyźnie. Kultura dotyczy natury i świata, a religia dotyczy Absolutności i Transcendencji ${ }^{20}$. Jezus Chrystus i wiara w Niego, który staje się centrum życia osobistego danej jednostki, będą motywowały ją nie tylko ku działaniom

\footnotetext{
${ }^{16}$ Por. A. Kłosowska, Kultura..., dz. cyt., s. 18.

${ }^{17}$ Por. R. Jaszczuk, Ewangelizacja kultur..., dz. cyt., s. 56-57.

${ }^{18}$ Por. tamże.

${ }^{19}$ Por. C.S. Bartnik, Personalizm, Lublin 2000, s. 452.

${ }^{20}$ Por. tamże.
} 
natury typowo religijnej (kult), ku transcendencji, ale także w wymiarze wertykalnym ku drugiemu człowiekowi i światu, zgodnie z przyjętym w chrześcijaństwie systemem wartości i w duchu odpowiedzialności. Wiara, przekonania religijne kształtują więc system wartości i prawo moralne, co z kolei znajduje odzwierciedlenie w przekonaniach i postawach życiowych. Dlatego dla chrześcijan ważne jest, aby przyjąć taką definicję kultury, która jest otwarta na porządek nadprzyrodzony i jest rozumiana jako dopełnienie natury. Każdy chrześcijanin jest odpowiedzialny zarówno za rozwój swojej wiary, jak też za twórcze przekształcanie świata w tym celu, by wszystkie wymiary ludzkiego życia napełnić wartościami Ewangelii. I to samo zadanie stoi przed nim, gdy idzie z Ewangelią do innych ludów czy kultur, aby zanieść im Chrystusa, a wraz z Nim nowe prawo miłości, które buduje cywilizację miłości.

Wielki przełom w rozwoju nauk o kulturze nastąpił w XIX w., kiedy to zrodziła się nowa dyscyplina naukowa nazwana antropologią kulturową, podejmująca badania naukowe nad kulturą. Antropologia kulturowa wyrosła z fascynacji światem pozaeuropejskim, który różnił się bardzo od znanego dotąd świata kultury ${ }^{21}$. Antropologowie zajmowali się początkowo fizyczną stroną człowieka, jego naturalnymi cechami i funkcjami, ale z czasem, podejmując coraz bardziej kompleksowe badania nad kulturą, w XX w. wkroczyli w dziedzinę badań odrębnych od natury. Należy stwierdzić, że antropologia kulturowa ma za cel poznanie kultury wszelkich typów i poziomów oraz analizę kultury powiązanej z człowiekiem jako jego dziełem i przedmiotem jego doświadczeń ${ }^{22}$. Antropologia w swym założeniu jest systematycznym badaniem człowieka i używając własnych narzędzi badawczych, próbuje odpowiedzieć na takie podstawowe kwestie, jak: kim są ludzie, w jaki sposób stali się tym kim są, jak się zachowują i dlaczego. Oczywiście inny jest status antropologa, a inny misjonarza, chociaż mogą pracować na tym samym terenie i wśród tej samej grupy społecznej. Antropologowi będzie zależało na zebraniu materiału etnograficznego, a misjonarz, który równie dobrze będzie dysponował bogatym materiałem antropologicznym, za cel będzie miał przepowiadanie Ewangelii. Dla jednych i drugich ważny jest człowiek i jego świat, chociaż w różnych wymiarach. Nie każdy misjonarz jest antropologiem albo antropolog misjonarzem, niemniej jednak każdy misjonarz może umiejętnie i z rozeznaniem wykorzystać wiedzę i odkrycia naukowe antropologów kulturowych, o ile ich kryteria badawcze i sposoby interpretacji są zgodne $\mathrm{z}$ duchem Ewangelii. Dlatego że misje Kościoła kierują się ku ludziom, a antropologia też w jakiś sposób skierowana jest ku człowiekowi i rzeczywistości, w której

${ }^{21}$ Por. W. Burszta, Różnorodność i tożsamość. Antropologia jako kulturowa refleksyjność, Poznań 2004, s. 30.

${ }^{22}$ Por. A. Kłosowska, Kultura..., dz. cyt., s. 17. 
on żyje, to podstawowa znajomość tej nauki i jej dorobku może być pomocna dla każdego, kto angażuje się w dzieło misyjne ${ }^{23}$.

Rozpatrując przydatność różnych koncepcji kultury w działalności misyjnej Kościoła i miejsce religii w kulturze, szczególną uwagę należy zwrócić na stanowisko antropologa Emila Durkheima (1858-1917), który sprowadzał religię do wzorcowej instytucji społecznej. Jako socjolog przyznał religii jedynie funkcję integracji społeczeństwa; w jego ujęciu włączała ona jednostkę do życia zbiorowego, integrowała zbiorowości i kultywowała tradycje grupowe. Nie tyle liczyła się treść wierzeń religijnych, ile ich funkcje zredukowane do integrowania społeczeństwa, którego upostaciowieniem miał być sakralny symbolizm religijny ${ }^{24}$. Chociaż jego koncepcja religii jako zjawiska społeczno-kulturowego jest ograniczona i nie da się jej pogodzić z autonomiczną istotą fenomenu religii, to sama przez się zakłada istnienie religii w ogóle. Stąd płynie wniosek, że zjawisko religii i potrzeby religijne człowieka są zjawiskiem uniwersalnym.

Kultura jest kategorią opisującą ważne aspekty życia ludzkiego, dlatego musi być uwzględniana $\mathrm{w}$ podejmowaniu działań ewangelizacyjno-misyjnych. Wydaje się więc zasadne przyjrzenie się różnym definicjom kultury, wypracowanym przez antropologię. Za ojca nowoczesnej antropologii uważany jest Edward Burnett Taylor, angielski antropolog (1832-1917) ${ }^{25}$, który wypracował jedną z pierwszych definicji kultury. W opublikowanym przez siebie w 1871 r. dziele Primitive Culture podał, że kultura, czyli cywilizacja, jest to pewna złożona całość, obejmująca wiedzę, wierzenia, sztukę, moralność, prawo, obyczaje i inne zdolności i nawyki, nabyte przez ludzi jako członków społeczeństwa ${ }^{26}$. Taylor wniósł dwa podstawowe elementy do definicji kultury, z których pierwszy podkreśla, że kultura jest czynnikiem decydującym o tym, że człowiek jest bytem społecznym, wykraczającym poza czysto naturalistyczną, biologiczną koncepcję. Kultura więc odróżnia człowieka od zwierząt, których istnienie pozostaje na poziomie czysto naturalnym. Drugim elementem jest stwierdzenie, że kultura jest społecznym dziedzictwem nabywanym przez grupę ludzką, w skład którego wchodzą: wiedza, wierzenia, sztuka, normy moralne, prawa, zwyczaje i inne elementy ${ }^{27}$.

Definicja Taylora zakłada obecność wierzeń i wymiaru religijnego w dziedzictwie kulturowym narodów i pokazuje drogę przekazu religii - jest ona

${ }^{23}$ Por. L.J. Luzbetak, Kościól a kultury. Nowe perspektywy w antropologii misyjnej, thum. S. Kotarski, Warszawa 1998, s. 36.

${ }^{24}$ Por. A. Kłosowska, Kultura..., dz. cyt., s. 32.

${ }^{25}$ Por. L.J. Luzbetak, Kościół a kultury, dz. cyt., s. 36.

${ }^{26}$ Por. C.S. Bartnik, Teologia kultury, Lublin 1999, s. 16; A.L. Kroeber, Istota kultury, Warszawa 2002, s. 152 n.

${ }^{27}$ Por. R. Jaszczuk, Ewangelizacja kultur..., dz. cyt., s. 58. 
nabywana przez ludzi jako członków danego społeczeństwa, czyli jest przekazywana z pokolenia na pokolenie i stanowi integralną część ich kultury. Jakie to może mieć znaczenie dla działalności misyjnej? Idąc do poszczególnych narodów czy grup społecznych, należy się spodziewać, że znajdzie się tam ukonstytuowany już system społeczny, świat wartości i wierzeń religijnych, które należy wziąć pod uwagę przy głoszeniu im Jezusa Chrystusa. Innym ważnym aspektem dla działań ewangelizacyjno-misyjnych, wynikającym z tej definicji, jest należyta troska o właściwe uformowanie serc, sumień i umysłów nowych chrześcijan, aby ci z kolei w takim samym duchu przekazywali otrzymaną wiarę kolejnym pokoleniom.

Inny amerykański antropolog Alfred Louis Kroeber (1876-1960) docenił pracę naukową Taylora, stwierdzając, że największym osiągnięciem antropologii XX w. było rozpowszechnienie i sprecyzowanie samego pojęcia kultury. Wcześniej istniały definicje raczej akademickie i badawcze, zwłaszcza historyczne, etnologiczne i socjologiczne. Sam Kroeber uważał, że kultury nie można zredukować ani do poziomu biologii (do czego dążyli ewolucjoniści), ani psychologii czy też sprowadzić jej do wymiaru społecznego. Kultura bazuje na wyższym i bardziej skomplikowanym poziomie organizacyjnym, kształtując zachowania i aktywności jednostek i grup. Wypracowana przez niego definicja kultury podaje, że kultura jest zwyczajowo przyjętym sposobem działania, odczuwania i myślenia, wybranym przez społeczeństwo spośród wielu innych, różnorodnych, możliwych potencjalnych sposobów by$\mathrm{cia}^{28}$. Zatrzymując się na jego stwierdzeniu, że kultura kształtuje zachowania i działania ludzkie, dostrzega się tu ogólnie przyjęte i realizowane w życiu elementy moralności, które wypływają z danego dziedzictwa kulturowego. Jeżeli następuje kontakt takich aspektów kultury z Ewangelią, to misjonarze, jak proponują dokumenty Kościoła, powinni rozpoznać, jakie wartości moralne są zgodne z Ewangelią, uznać je za swoje, a dane dziedzictwo kulturowe ubogacić wartościami ewangelicznymi.

A. Kroeber, pracując nad uporządkowaniem różnych określeń kultury, wraz z innym antropologiem amerykańskim Clyde Kluckhonem (1905-1960), zebrał aż 300 jej różnych definicji, spośród których wiele było jakby echem wyżej wspomnianej definicji Taylora ${ }^{29}$. W swoim wspólnym dziele Culture zawarli 164 określenia kultury, sprowadzając definicje kultury do sześciu typów: opisowych, historycznych, normatywnych, psychologicznych, strukturalnych, genetycznych ${ }^{30}$. Ich dorobek naukowy ma znaczenie dla rozwoju katolickiej antropologii misyjnej.

\footnotetext{
${ }^{28}$ Por. W. Kawecki, Kościót i kultura $w$ dialogu, Kraków 2008, s. 98.

${ }^{29}$ Por. L.J. Luzbetak, Kościól a kultury, dz. cyt., s. 149.

${ }^{30}$ Por. C.S. Bartnik, Teologia kultury, dz. cyt., s. 16.
} 
Wśród współczesnych definicji kultury na szczególną uwagę zasługuje personalistyczna koncepcja kultury, uznająca człowieka jako osobę za podmiot (sprawcę) świadomego i wolnego działania, działania moralnego, przez które ten człowiek się rozwija, tworzy kulturę i buduje życie społeczne. Kultura jest sposobem istnienia człowieka, jego twórczego działania i przetwarzania świata, co dobrze oddają słowa Arystotelesa: genus humanum arte et ratione vivit - „rodzaj ludzki żyje dzięki twórczości i rozumowi”31, powtórzone przez św. Tomasza z Akwinu, a także często przytaczane przez Jana Pawła II. Według personalistycznej koncepcji przez kulturę rozumie się całość doznań i działań człowieka, zarówno wewnętrznych, jak i zewnętrznych, zmierzających do rozwijania własnego człowieczeństwa, zgodnie z prawdą o człowieku jako osobie, ukierunkowaną na dojrzewanie osobowe i ochronę godności własnej i innych ${ }^{32}$. Człowiek ma stawać się bardziej człowiekiem. Osoba ludzka, zmieniając według swoich koncepcji zastaną rzeczywistość (naturę, tzn. świat i siebie), pozostawia w nich typowo ludzki ślad, co jest określane mianem humanizacji natury. Jest ona także istotą rozumną, dlatego można powiedzieć, że kultura jest dokonaną przez człowieka racjonalizacją (intelektualizacją) natury ${ }^{33}$.

Personalistyczna koncepcja kultury jawi się więc jako całokształt sposobów i środków realizowania się człowieka ku pełni człowieczeństwa poprzez wychowanie, edukację, osobisty trud formowania własnej osoby oraz kształtowania wolności i odpowiedzialności za siebie i innych ${ }^{34}$. Człowiek tworzy kulturę i jednocześnie jest jej odbiorcą, bo żyje w niej i w niej się porusza. Ma wpływ na otaczający go świat przez podejmowanie osobistych decyzji i własne wybory. Dlatego dobry przykład każdego chrześcijanina ma ogromne znaczenie dla ewangelizacji. Już sama postawa uformowana według chrześcijańskich wartości jest głoszeniem Ewangelii i może wielu pociągnąć do Chrystusa, czy to na terenach ściśle misyjnych, czy w krajach, gdzie prowadzi się duszpasterstwo albo nową ewangelizację. Także świat chrześcijańskiej sztuki: muzyka, obraz, literatura, architektura i inne, dopełnia dzieła ewangelizacji.

${ }^{31}$ Tamże, s. 57; por. także Z. Zdybicka, Jaka kultura?, w: W trosce o kulturę, red. B. Bejze, Warszawa 1996, s. 377 - ratio et arte vivit autorka tłumaczy jako „człowiek żyje rozumem i twórczością".

${ }^{32}$ Por. K. Olbrycht, Godność osoby źródtem i wartościq kultury chrześcijańskiej Europy, w: Osobowy wymiar kultury, red. J. Dobrzyńska, Warszawa 2004, s. 25.

${ }^{33}$ Por. Z. Zdybicka, Człowiek i religia, Lublin 1977, s. 183.

${ }^{34}$ Por. S. Kasprzak, Organizacja działalności misyjnej Kościoła w świetle prawa kanonicznego, Lublin 1999, s. 113. 


\section{Chrześcijaństwo w spotkaniu z kulturą}

Kościół od samego początku głoszenia Ewangelii spotykał się i konfrontował z różnymi kulturami, przekonując się, że w Chrystusie Boże obietnice przyjmują wymiar uniwersalny i ludzie wszystkich krajów i tradycji mają jednakowy dostęp do skarbu wiary. Dlatego należy ukazać także w perspektywie historycznej, jak Kościół na przestrzeni wieków, głosząc Ewangelię narodom, przekraczał granice państw i kultur, formułując jednocześnie zasady inkulturacji. Taki rys historyczny pomoże w pełniejszym świetle zobaczyć współczesne problemy inkulturacji, a także odsłoni bogate nauczanie Kościoła dotyczące kontaktu Ewangelii z różnymi kulturami.

\subsection{Doświadczenie Kościoła pierwszych wieków}

Kościół, przekazując prawdę objawioną, szybko przekonał się o powszechności głoszonego orędzia, ale także zetknął się z przeszkodami, jakie wynikały z różnic kulturowych. W spotkaniu wiary Kościoła z różnymi kulturami zrodziła się $\mathrm{w}$ praktyce nowa rzeczywistość ${ }^{35}$. Jest tu mowa o tzw. kulturze Zachodu ${ }^{36}$, która stała się fundamentem współczesnej nam światowej cywilizacji. Kultura ta miała swój początek w antycznym basenie Morza Śródziemnego i powstała w wyniku współistnienia i funkcjonowania czterech kultur:

1) profetycznej - uosobionej przez takie postacie, jak Izajasz i Jeremiasz, mającej hebrajsko-chrześcijańskie korzenie; najważniejsze znaczenie miały: transcendencja i przynależność do Boga, poszanowanie wolności i świata wartości, nawrócenie się i oddanie ostatecznemu celowi ${ }^{37}$;

2) akademickiej - reprezentowanej przez Platona i Arystotelesa; kultura filozofów i ludzi wykształconych, z której obficie czerpali ojcowie Kościoła, w której widać ścisłe powiązania między Atenami a Jerozolimą, co można przełożyć na relacje rozumu i objawienia, nauki i religii, wiary i kultury ${ }^{38}$;

3) kultury humanistycznej - uobecnionej w postaciach poetów, pisarzy, dramaturgów, oratorów, takich jak np.: Homer, Sokrates, Wergiliusz, Cyceron, Ambroży i Augustyn, dla której istotne jest poruszanie się w świecie: literatury pięknej, poezji, historii, teatru i retoryki, i czerpanie z nich; do osiągnięcia tego typu znajomości kultury dochodziło się też przez możliwość odbycia regularnych studiów ${ }^{39}$;

\footnotetext{
${ }^{35}$ Por. Jan Paweł II, Fides et ratio, nr 70.

${ }^{36}$ Por. W. Kawecki, Kościót i kultura $w$ dialogu, dz. cyt., s. 19.

${ }^{37}$ Por. tamże.

${ }^{38}$ Por. tamże, s. 19 n.

${ }^{39}$ Por. tamże, s. 20.
} 
4) kultury artystycznej - która dążyła do obrazowego przedstawienia tajemnic życia i otaczającego świata jako kultura malarzy, rzeźbiarzy, architektów, muzyków i wielu innych twórców sztuki.

Wymienione wyżej cztery typy kultur, z którymi chrześcijaństwo weszło w kontakt, przyczyniły się do zbudowania cywilizacji, którą współcześnie nazywamy cywilizacją zachodnią ${ }^{40}$. Chrześcijaństwo zrosło się z owymi wszystkimi elementami, jak pragnienie transcendencji Boga, umiłowanie mądrości, erudycja i poczucie piękna, a następnie posłużyło się nimi, by od początku integrować w sobie wiarę i kulturę. Zauważa się wyraźnie, że chrześcijaństwo, kształtując Europę, dało początek cywilizacji narodów i ich kulturom. Przyjęta wiara stopniowo przenikała wszystkie elementy życia społecznego i w nich się wyrażała $^{41}$. Dzieła sztuki były jasną i oczywistą ekspresją otrzymanych i przyjętych wartości chrześcijańskich i jednocześnie sposobem ich głoszenia, co sprawiało, że kultury narodowe rozwijały się na bogatym fundamencie Ewangelii. Wraz z wiarą chrześcijańską do nowych narodów i ich kultur stopniowo przenikały więc wartości ewangeliczne. Przypuszcza się, że w tej zintegrowanej chrześcijańskiej kulturze wzorce postępowania były jasno określone, a przekazywanie dziedzictwa kulturowego było tożsame z przekazywaniem wiary w Jezusa Chrystusa, co wzmacniało proces ewangelizacji.

Kościół wciąż będzie poszukiwał najlepszej drogi przekazu wiary w Chrystusa, bo jego istotą jest misyjność, postawa dynamiczna, nie statyczna. Chrześcijaństwo ze swej natury będzie chciało zawsze przekraczać granice pokoleń i kultur, by nieść Chrystusa, który przez wcielenie zjednoczył się z każdym człowiekiem i zbawił wszystkich.

\subsection{Przedsoborowe rozumienie kultury}

Kościół ożywiony działaniem Ducha Ożywiciela, pragnie pobudzać ducha misyjnego w swoim ludzie i w Jego świetle określać kierunek działalności misyjnej. Z drugiej strony Kościół zawsze zwraca uwagę na znaki czasu, gotowy jest do ich rozpoznania i interpretacji, by w zmieniających się warunkach kontynuować dzieło ewangelizacji.

Wiek XIX przyniósł nową świadomość misyjną ówczesnemu światu chrześcijańskiemu, co zaowocowało ożywieniem ducha misyjnego i zaangażowaniem na polu misyjnym. Do pracy tej włączyli się członkowie starych i nowych zgromadzeń misyjnych. Na uwagę zasługuje fakt, że na początku

${ }^{40}$ Także w rozumieniu niektórych antropologów XIX w. kultura oznaczała po prostu Zachód, tę swego rodzaju jedynie racjonalną, historyczną, rozwojową i „nabożną” całość. Por. W. Burszta, Różnorodność i tożsamość. Antropologia jako kulturowa refleksyjność, dz. cyt., s. 30.

${ }^{41}$ Por. W. Kawecki, Kościól i kultura $w$ dialogu, dz. cyt., s. 20n. 
XIX w. było ok. 300 misjonarzy katolickich, podczas gdy pod koniec tegoż stulecia aż 25 tysięcy ${ }^{42}$. Już przed Soborem Watykańskim II Kościół doświadczał w swej działalności misyjnej napięć w kontaktach z wieloma kulturami, co znalazło wyraz w przedsoborowej doktrynie misyjnej Kościoła. Wzrastało zainteresowanie misjami, a tematem pierwszoplanowym w myśli misjologicznej i teologicznej było przystosowanie Kościoła do otaczających go warunków kulturowych ${ }^{43}$. Także misjonarze często byli tymi, którzy w epoce niewolnictwa bronili praw ludności tubylczej i nie byli przychylnie nastawieni do łączenia misji z nacjonalizmem. To tworzyło konflikty i napięcia między personelem misyjnym a organizmami kolonialnymi ${ }^{44}$. Dlatego nauczanie Kościoła dotyczące misji i inkulturacji nie mogło także pomijać takich palących kwestii, jak: obrona praw człowieka, sprawa społeczna, kształtowanie ludzkich sumień i właściwa formacja tubylczego kleru.

Znamienną postacią tego okresu był papież Leon XIII (1878-1903), który otworzył Kościół na nową kulturę Zachodu i na dialog z nią. Niejednokrotnie sam był oskarżany o odrzucenie nowej cywilizacji i o zacofaną postawę w konfrontacji z prądami oświeceniowymi, obecnymi w XIX-wiecznej Europie. Leon XIII odważnie podjął dialog z kulturą swoich czasów, pokazując chrześcijaństwo jako penetrujące ową kulturę i stanowiące o autentycznych wartościach ludzkiej cywilizacji. Nowa kultura, nowe społeczeństwo wymagało nowej odpowiedzi Kościoła również na wspomnianą kwestię społeczną. W encyklice Rerum novarum papież proponował rozwiązywanie trudnych problemów społeczno-kulturowych przez praktykowanie takich cnót chrześcijańskich, jak sprawiedliwość i przyjaźń ${ }^{45}$. Jeżeli obydwie poróżnione strony będą posłuszne przykazaniom chrześcijańskim, „zapanuje między nimi nie tylko prosta przyjaźń, ale i miłość bratnia"46.

Kolejni przedsoborowi papieże również podejmowali i rozwijali tematykę spotkania Ewangelii z kulturami. Papież Benedykt XV (1914-1922) w Liście apostolskim Maximum illud (1919) uważanym za ,wielką kartę misyjną”, także nazwanym nowoczesną ,encykliką” misyjną, w nowy sposób ujmuje teologiczną wizję misji. Naucza, że na tym polega uniwersalizm Dobrej Nowiny, iż nie może ona identyfikować się z żadną kulturą czy narodem ${ }^{47}$. Refleksja Benedykta XV na temat spotkania Ewangelii z kulturami jest w jakimś sen-

${ }^{42}$ Por. L.J. Luzbetak, Kościól a kultury, dz. cyt., s. 111, 113.

${ }^{43}$ Por. R. Jaszczuk, Ewangelizacja kultur..., dz. cyt., s. 92.

${ }^{44}$ Por. S.B. Bevans, R.P. Schroeder, Constants in Context. A Theology of Mission for Today, New York 2004, s. 236.

${ }^{45}$ Por. W. Kawecki, Kościót i kultura $w$ dialogu, dz. cyt., s. 36n.

${ }^{46}$ Leon XIII, Rerum novarum, nr 21, w: Dokumenty nauki społecznej Kościoła, red. M. Radwan, L. Dyczewski, A. Stanowski, Rzym-Lublin 1987, s. 52.

${ }^{47}$ Por. A. Miotk, Aż na krańce ziemi. Popularna historia misji, Warszawa 2005, s. 171. 
sie nowatorska. Papież zalecał, aby Kościół, zakładając wspólnoty w nowych krajach, starał się brać pod uwagę specyficzne cechy ewangelizowanych narodów. Podkreślał konieczność dekolonizacji i odrzucił misje typu kolonialnego, które preferowały kulturę krajów, z których pochodzili misjonarze. Następnie widział potrzebę wzmocnienia Kościołów lokalnych przez popieranie i dobrą formację rodzimego kleru, co wzmocni proces zakorzeniania się Kościoła powszechnego w krajach misyjnych. Ponadto wszystkich misjonarzy winno cechować nastawienie ponadnarodowe, pozbawione cech typowo nacjonalistycznych $^{48}$. Przekonania i wskazówki Benedykta XV z okresu kwitnącego kolonializmu już wtedy nie pozwalały na wiązanie polityki kolonialnej z działalnością misyjną. Nauczanie papieży kształtowało właściwe postawy misjonarskie, a także jasno rozgraniczało ewangelizację od nacjonalizmu.

Kolejnym krokiem w rozwoju idei kultury w perspektywie działalności misyjnej jest encyklika Piusa XII (1939-1958) Evangelii praecones (1951), w której papież formułuje zasadę adaptacji misyjnej, szanującej to, co dobre i szlachetne w innych kulturach. Papież nauczał, że Kościół od swych początków aż do współczesnych mu czasów kierował się tą zasadą, że Ewangelia, którą przyjęły różne ludy, nie powinna niszczyć ani tłumić tego, co każda z tych kultur ma dobrego, szlachetnego i pięknego. Kościół, głosząc Ewangelię i pragnąc ubogacić kulturę ludów wartościami chrześcijańskimi, „nie zachowuje się jak ten, kto bez żadnego rozumnego powodu rąbie, tnie, niszczy bujnie rosnący las, lecz raczej jak ten, kto na dziczkach zaszczepia szlachetną gałązkę, aby kiedyś rodziły się na nich i dojrzewały milsze i słodsze owoce"49. Koncepcja papieża była dużym krokiem w stronę poszanowania innych kultur i religii, wyraźnie też otwierała drzwi Kościoła dla semina verbi już w nich obecnych.

Pewną syntezą myśli przedsoborowej w odniesieniu do dzieła misyjnego jest encyklika Jana XXIII (1958-1963), Princeps pastorum (1959), wydana z okazji 40-lecia Maximum illud Benedykta XV. W tym dokumencie Jan XXIII odrzuca wszelkie próby utożsamiania Kościoła z kulturą basenu Morza Śródziemnego, mówiąc, że Kościół nie utożsamia się z żadną kulturą, nawet z zachodnią, z którą przez wieki historycznie był związany. Papież naucza, że Kościół „zawsze aprobuje i chętnie przyjmuje w siebie, a nawet czynnie pobudza to wszystko, co przynosi zaszczyt myśli i duchowi ludzkiemu, chociażby wywodziło się to z innych części globu"50. To stwierdzenie przypomina, że

${ }^{48}$ Por. R. Jaszczuk, Ewangelizacja kultur..., dz. cyt., s. 93n.; por. także A. Miotk, Aż na krańce ziemi..., dz. cyt., s. 171.

${ }^{49}$ R. Jaszczuk, Ewangelizacja kultur..., dz. cyt., s. 97n.

${ }^{50}$ Breviarium missionum. Wybór dokumentów Kościoła dotyczacych dzieła misyjnego, t. 1, red. B. Wodecki, F. Wodecki, F. Zapłata, Warszawa 1979, s. 350n. 
chociaż Kościół powstał i historycznie ukształtował się w kontakcie z kulturami basenu Morza Śródziemnego, to orędzie zbawcze nie może być związane z żadną partykularną kulturą.

Z przedsoborowego nauczania Kościoła o jego odniesieniu do wzajemnej relacji Ewangelii i kultury można wysnuć kilka wniosków. Niektórzy katolicy tego okresu uważali, że cywilizacja i ewangelizacja są w jakiś sposób ze sobą powiązane, interpretując cywilizację etnocentrycznie, czyli jako przenoszenie własnych modeli kulturowych. Chociaż uważali inne religie i kultury za „nie całkiem złe”, to jednak ,godne współczucia”, pogrążone w zabobonach ${ }^{51}$. Zarówno katolicy, jak i protestanci uważali, że główną rolą misjonarza jest praca na polu edukacji i służby zdrowia, by podnieść poziom wykształcenia, poprawić warunki bytowe oraz kondycję fizyczną i duchową ludzi. Z drugiej jednak strony jest też prawdą, że wraz z działalnością na polu edukacyjnym i opieki medycznej, co wspiera rozwój ludzki, także Ewangelia miała szansę przenikania do umysłów i serc nowych ludów oraz kształtowania ich postaw moralnych. Jest czymś oczywistym, że edukacja oparta na wartościach ewangelicznych wspiera dzieło ewangelizacji i przyczynia się do kształtowania rodzimej kultury chrześcijańskiej.

Podsumowując, należy stwierdzić, że rozumienie kultury w teologii przedsoborowej nie było jednoznaczne. $Z$ jednej strony Kościół uczył się nowego dialogu z kulturą Zachodu, która stawała się coraz bardziej zeświecczona, wskutek czego nie sprzyjała wzrostowi wiary. Z drugiej zobaczył naglącą potrzebę wejścia w dialog i dowartościowania kultur niechrześcijańskich, wśród których prowadził działalność misyjną. Można przyjąć, że stosunek Kościoła do kultury w jej szerokim znaczeniu charakteryzowały trzy postawy:

- niepokojąca wrogość - oparta na przekonaniu, że kultura jest zasadniczo ,chora",

- naiwna akceptacja - polega na niedostrzeganiu niebezpieczeństw w konfrontacji ze złożoną rzeczywistością kulturową,

- rozwaga w tworzeniu kultury - jako postawa właściwa, poprzez którą Kościół popiera przekonanie, że człowiek w swoim człowieczeństwie może się realizować, wzrastając $\mathrm{w}$ harmonii pomiędzy aspiracjami o własnym rozwoju a wartościami ewangelicznymi.

Wysoka kultura wspiera religijność, a brak kultury, zwłaszcza duchowej, może skutecznie blokować jej rozwój, przy założeniu oczywiście, że przez wysoką kulturę rozumie się życie zgodne z wartościami Ewangelii ${ }^{52}$. Droga, którą przeszedł Kościół w odniesieniu do rozumienia terminu kultura w nauczaniu przedsoborowym, bezsprzecznie była ważnym przygotowaniem do

\footnotetext{
${ }^{51}$ Por. L.J. Luzbetak, Kościót a kultury, dz. cyt., s. $115 \mathrm{n}$.

${ }^{52}$ Por. W. Kawecki, Kościót i kultura w dialogu, dz. cyt., s. 101.
} 
postawienia kolejnego kroku, jakim stało się soborowe sprecyzowanie definicji kultury.

\subsection{Soborowa definicja kultury}

Punktem wyjścia do współczesnych rozważań nad rozumieniem kultury i procesu inkulturacji jest nauczanie Soboru Watykańskiego II. Nie tylko dokumenty końcowe jako efekt pracy Soboru rzuciły nowe światło na zagadnienie kultury, ale sam fakt, że Sobór zgromadził przedstawicieli już nie tylko Europy i starych kultur, ale całego świata, wskutek czego cechował go pluralizm mentalnościowy i kulturowy, co było jasnym obrazem uniwersalności Kościoła. Analiza dokumentów soborowych wykazała, że wyraz „kultura” pojawia się w nich ponad 90 razy, a termin „kulturalny” - więcej niż 30 razy $^{53}$, co wskazuje na aktualność tej problematyki. Jeśli chodzi o samą terminologię, to w oficjalnym nauczaniu aż do Soboru Watykańskiego II Kościół, mówiąc o kulturze, używał określeń „cywilizacja” lub „cywilizacja chrześcijańska”. W dokumencie soborowym, w Konstytucji duszpasterskiej o Kościele w świecie współczesnym, co poniekąd uważa się za moment przełomowy, podano po raz pierwszy nowoczesną definicję kultury, a brzmi ona następująco:

Słowem kultura w znaczeniu ogólnym określa się wszystko, za pomocą czego człowiek doskonali i rozwija różnorodne dary ducha i ciała, usiłuje dzięki poznaniu i pracy podporządkować swojej władzy świat, zaś przez postęp obyczajów i różnych instytucji czyni bardziej ludzkim życie społeczne zarówno w rodzinie, jak i w całej społeczności obywatelskiej, a na przestrzeni dziejów wyraża, przekazuje i zachowuje w swoich dziełach wielkie doświadczenia duchowe i pragnienia po to, by służyły rozwojowi wielu, a nawet całego rodzaju ludzkiego ${ }^{54}$.

Soborowa definicja kultury podkreśla, że człowiek jest powołany do wszechstronnego rozwoju duchowego i cielesnego, a przez poznanie i pracę rozszerza swoją władzę nad światem. Następnie przez swoje twórcze działanie przyczynia się do humanizacji życia społecznego we wszystkich jego wymiarach i stara się o przekazanie tego dziedzictwa kulturowego innym ludziom, a nawet całej ludzkości ${ }^{55}$.

Soborowa definicja podkreśla personalistyczny wymiar kultury, zwracając uwagę na obecne w niej wartości duchowe oraz wiążąc mocniej kulturę z człowiekiem jako jej twórcą i odbiorcą. Właściwością bowiem osoby ludzkiej jest, jak naucza Sobór, dochodzenie właśnie przez kulturę, czyli przez roz-

\footnotetext{
${ }^{53}$ Por. R. Jaszczuk, Ewangelizacja kultur..., dz. cyt., s. 103.

${ }^{54}$ Gaudium et spes, $\mathrm{nr} 53$.

${ }^{55}$ Por. C.S. Bartnik, dz. cyt., s. 16 n.
} 
wijanie dóbr i wartości naturalnych, do prawdziwego i pełnego człowieczeństwa. „Gdziekolwiek więc chodzi o życie ludzkie, natura i kultura łączą się ze sobą jak najściślej"56.

Ostatni Sobór nie tylko podał definicję kultury, ale sprecyzował, jak w praktyce widzi jej zastosowanie w działalności ewangelizacyjnej, czyli w konkretnym dialogu kultur z Ewangelią. Podaje bardzo ważne stwierdzenia, mianowicie że Kościół jest

posłany do wszystkich ludów wszelkiego czasu i miejsc, nie wiąże się wyłącznie i nierozerwalnie z żadną rasą ani narodem, żadną konkretną obyczajowością, żadnym dawnym ani też nowym zwyczajem. Trwając przy własnej tradycji, a równocześnie świadomy swojej powszechnej misji, jest zdolny wchodzić w związek z różnymi formami kultury, przez co ubogaca się zarówno sam Kościól, jak i różne kultury ${ }^{57}$.

Kościół dlatego, że jest uniwersalny, powszechny i skierowany z woli Chrystusa do wszystkich ludów i narodów („Idźcie i nauczajcie wszystkie narody" - Mt 28,19), jest otwarty na każdą kulturę, gotowy ubogacić się ich wartościami, a jednocześnie daje $\mathrm{w}$ zamian osobę Jezusa i całe bogactwo Ewangelii. Jeżeli tak bardzo podkreśla się dziś personalistyczny wymiar kultury i podmiotowość ludzkiej twórczości, to również ten aspekt może być bardzo pomocny w działalności ewangelizacyjno-misyjnej, w nawiązywaniu tej szczególnej osobistej więzi z osobą Jezusa Chrystusa, który jako jedyny może skierować stęsknione ludzkie serce ku Bogu oraz pokazać inną, głębszą perspektywę życia.

W kontekście rozważań nad wzajemnymi odniesieniami kultury i działalności misyjnej należy wymienić Dekret o działalności misyjnej Kościoła Ad gentes, który mówi o właściwym przygotowaniu się do dialogu z nowymi, nieznanymi kulturami. Jest faktem, że poznanie objawienia Bożego zawsze dokonuje się dwutorowo przez wiarę i rozum. Dlatego w tym, co należy do porządku rozumu, Kościół potwierdza prawowitą autonomię kultury ludzkiej, a zwłaszcza nauk ${ }^{58}$, otwierając umysły ludzkie na twórcze poszukiwania odpowiedzi. To wymaga należytego przygotowania i umiejętności, na co wskazuje Ad gentes, ucząc, że aby działalność misyjna była poprawna i uporządkowana,

${ }^{56}$ Gaudium et spes, $\mathrm{nr} 53$.

57 Tamże, nr 58.

${ }^{58}$ Por. Gaudium et spes, nr 59. „Święty Sobór, przypominając to, o czym pouczył Sobór Watykański I, głosi, że «istnieje dwojaki, różny porządek poznania», a mianowicie porządek wiary i rozumu. Kościół zaś nie zakazuje tego, by «ludzkie sztuki i nauki [...] każda w swoim zakresie posługiwały się własnymi zasadami i własną metodą»; dlatego «uznając tę słuszną wolność», potwierdza prawowitą autonomię kultury ludzkiej, a zwłaszcza nauk”. 
wymaga się od przekazicieli Ewangelii, aby byli naukowo przygotowani do swoich zadań, szczególnie do dialogu z religiami i kulturami niechrześcijańskimi. Ponadto powinni oni być wspomagani przez owocną współpracę dla dobra misji wielu instytutów naukowych, takich jak: misjologia, etnologia, lingwistyka, historia, religioznawstwo i socjologia ${ }^{59}$, by ten dialog z kulturami czy religiami ostatecznie służył nadrzędnym celom misji, jakimi są chwała Boża i zbawienie człowieka. Do dialogu z innymi kulturami należy się więc odpowiednio przygotować, twórczo korzystając z dorobku dostępnych naukowych osiągnięć.

\section{Zakończenie. Zastosowanie misjologiczne}

Nauczanie soborowe na temat kultury nie pozostało oczywiście bez echa. Jego owocność jest szeroko znana i uznana w kręgach misjologów i misjonarzy, a samo nauczanie wciąż pogłębiane i rozwijane. Kontynuując rozważania na temat stosunku Ewangelii do różnych kultur, by lepiej zrozumieć przydatność i zastosowanie tej dziedziny do działań misyjnych, dobrze jest jeszcze odwołać się do dwóch posoborowych dokumentów Kościoła: Evangelii nuntiandi (1975) Pawła VI (1963-1978) i przytaczanego wcześniej Redemptoris missio (1990) Jana Pawła II (1978-2005).

W Adhortacji Evangelii nuntiandi Paweł VI określił kulturę nie tylko jako wiedzę i szczególne zdolności, zarezerwowane jedynie dla elit, ale jako system wartościowania, do którego należą kryteria oceny, hierarchia dóbr, postawy i nawyki myślowe, bodźce postępowania i ludzkie modele życiowe ${ }^{60}$. W jego nauczaniu dostrzega się kontynuację nauczania poprzedników, gdy stwierdza, że Ewangelia nie utożsamia się z żadną kulturą, ale może na nie wpływać, przenikać je i przemieniać ${ }^{61}$. Papież podkreśla też znaczenie celu procesu ewangelizacji, jakim jest głęboka wewnętrzna przemiana człowieka i kształtowanie jego sumienia. Kościół wtedy naprawdę ewangelizuje, kiedy stara się przemienić mocą Dobrej Nowiny sumienie poszczególnego człowieka i całych społeczeństw, a następnie przepoić duchem Ewangelii całą ich działalność i środowiska życia ${ }^{62}$. Gdy Ewangelia naprawdę dotrze do serca człowieka, taka osoba jest zdolna wypełnić nią całą przestrzeń swego życia i na tym właśnie ma polegać właściwe zrozumienie i wypełnianie powołania chrześcijańskiego.

\footnotetext{
${ }^{59}$ Por. Ad gentes, dz. cyt., nr 34.

${ }^{60}$ Por. Paweł VI, Evangelii nuntiandi, nr 19.

${ }^{61}$ Por. tamże, $\mathrm{nr} 20$.

${ }^{62}$ Por. tamże, $\mathrm{nr} 18,20$.
} 
Jan Paweł II w Encyklice misyjnej Redemptoris missio potwierdza, że Kościół szanuje ludzi i ich kultury. Jednocześnie przypomina o konieczności wejścia z Ewangelią na nowe obszary kulturowe, czyli współczesne areopagi misji ${ }^{63}$. Papież popiera proces inkulturacji, poprzez który

Kościół wciela Ewangelię w różne kultury i jednocześnie wprowadza narody z ich kulturami do swej własnej wspólnoty; przekazuje im własne wartości, przyjmując wszystko to, co jest w nich dobre i odnawiając je od wewnątrz. Ze swej strony przez inkulturację Kościół staje się bardziej zrozumiałym znakiem tego, czym jest, i coraz odpowiedniejszym narzędziem misji ${ }^{64}$.

Jan Paweł II od początku swego pontyfikatu, zwłaszcza realizując liczne podróże apostolskie, wskazywał na potrzebę inkulturacji, która wiąże się z dziełem zbawienia i zadaniem ewangelizacji. We wspomnianej encyklice podał też zasady, które należy wziąć pod uwagę w procesie inkulturacji; w spotkaniu Ewangelii z innymi kulturami trzeba zachować zasadę integralności głoszonego ewangelicznego orędzia i zasadę jedności z Kościołem ${ }^{65}$, co jest jasną wskazówką dla wszelkich kroków na gruncie misyjnym i misjologicznym. Głosząc Chrystusa i Jego Słowo, nie traktujemy wybiórczo Jego nauki, ale przekazujemy cały depozyt wiary, pozostając w relacji jedności i posłuszeństwa do Urzędu Nauczycielskiego Kościoła.

Chociaż Kościół jest powołany do nieustannego dialogu z kulturą, to wzajemny kontakt kultury i Ewangelii nie jest zawsze procesem łatwym i prostym, prowadzącym do wzajemnego ubogacenia i do pożądanych owoców przepojenia kultur wartościami ewangelicznymi. Należy być świadomym, że pomiędzy różnymi dziedzinami kultury a religią istnieje, ulegająca zmianie w dziejach kultury i religii, relacja wzajemnego napięcia: od jedności i zgodności, przez dystans i obcość aż do zeświecczenia religii lub jej radykalnego odwrócenia się od świata. Dla chrześcijaństwa typowe jest to, że nie będąc z tego świata, pozostaje z nim jak najściślej związany ${ }^{66}$, bo jest do niego posłany.

${ }^{63}$ Por. Jan Paweł II, Redemptoris missio, dz. cyt., nr 37, 39.

Pojęcie „kręgi kulturowe” funkcjonuje w etnologii od wielu lat. Po raz pierwszy pojawiło się w nauce w poł. XIX w. Nie zostało jednak bliżej opisane i miało wiele znaczeń. Na przełomie XIX i XX w., a także później „krąg kulturowy” wskazywał na daną przestrzeń geograficzną, w której znajdują się specyficzne dla niej elementy kulturowe, takie jak: religia i moralność, struktura społeczna, gospodarka, czy także wytwory człowieka. Obecnie w mowie potocznej określa specyfikę danej kultury, w której żyją większe lub mniejsze grupy ludzkie, społeczne, jak narody. Por. E. Sakowicz, Kręgi kulturowe i religijne, „Misje Dzisiaj” 6 (2010), s. 6.

${ }^{64}$ Jan Paweł II, Redemptoris missio, dz. cyt., nr 52.

${ }^{65}$ Por. tamże, nr 54.

${ }^{66}$ Por. F. König, K. Waldenfels, Kultura/Kultury, dz. cyt., s. 211. 
Amerykański antropolog Louis J. Luzbetak SVD podaje warunki, które muszą być spełnione, by misjologia uznała dany model kultury za dobry. Otóż wtedy, kiedy jest on sprawdzony i odpowiedni misjologicznie, tzn. jest on teoretycznie i praktycznie przydatny dla misji. Taki model powinien - uwzględniając działalność akademicką - pomagać w zrozumieniu teologii misji, historii misji oraz ułatwić „konstrukcje teoretyczne teologii lokalnych"67. Wychodząc poza obszar akademicki, misjologiczny model kultury musi uwzględniać takie aspekty działalności misyjnej, jak proces wchodzenia w pozachrześcijańską społeczność oraz przekraczanie barier pokoleniowych. Następnie w procesie identyfikacji kulturowej należy zwrócić uwagę na utrzymywanie kontaktów z daną społecznością lub jej częścią, szczególnie wtedy, gdy jej sposoby bycia, znaczenia i wartości różnią się od znanych duszpasterzowi. Ważne jest komunikowanie się zgodne $\mathrm{z}$ daną kulturą, tzn. słuchanie i wypowiadanie się zarówno w sposób werbalny, jak i niewerbalny. Należy towarzyszyć i kierować pożądaną zmianą społeczną w sposób jak najbardziej skuteczny i najmniej bolesny, współpracując z tymi, którzy bezpośrednio doświadczają jej efektów ${ }^{68}$. Według Luzbetaka, aby jakiś model kultury był misjologicznie przydatny, powinien czynić misje bardziej zrozumiałe zarówno dla Kościoła lokalnego, jak i dla Kościoła powszechnego, dla duszpasterzy rodzimych, jak i pochodzących z zagranicy. Taki model powinien stanowić ramy, w obrębie których można będzie prowadzić normalną pracę duszpasterską, ewangelizacyjną oraz samo życie chrześcijańskie ${ }^{69}$.

Konkludując, stwierdza się, że dla teologii katolickiej najważniejszym i podstawowym kryterium oceny kultury jest jej rola w realizowaniu ostatecznego celu człowieka, czyli zbawienia w postaci udziału w pełni życia Bożego, przez integralny rozwój osoby ludzkiej, przy poszanowaniu jej godności i wolności ${ }^{70}$. Działalność misyjna Kościoła jest więc głoszeniem tego zbawienia wszystkim narodom, a w stosunku do poszczególnego człowieka „Kościół proponuje, niczego nie narzuca: szanuje ludzi i kultury, zatrzymuje się przed sanktuarium sumienia" "71, gdyż Kościół jedynie proponuje, ale niczego nie narzuca.

Podmiotem kultury i jej przedmiotem jest ostatecznie człowiek, a w dziedzinie kultury najważniejsza jest ,uprawa” człowieka, czyli wychowanie go, by żył w prawdzie, czynił dobro, tworzył i kontemplował piękno oraz by zmie-

\footnotetext{
${ }^{67}$ L.J. Luzbetak, Kościól a kultury, dz. cyt., s. 152.

${ }^{68}$ Por. tamże.

${ }^{69}$ Por. tamże, s. 152 n.

${ }^{70}$ Por. A.R. Crollius, Inkulturacja, w: Kościót misyjny, red. S. Karotempler, tłum. R. Dziura, A. Halemba, Warszawa 1997, s. 129.

${ }^{71}$ Jan Paweł II, Redemptoris missio, dz. cyt., nr 39.
} 
rzał do poznania i miłowania Boga i drugiego człowieka ${ }^{72}$. Kultura, chociaż niedoskonała jak każde dzieło człowieka, odgrywa w życiu każdego człowieka istotną rolę w jego drodze do Boga. Wszyscy ludzie, którzy są jak pielgrzymi $\mathrm{w}$ drodze, powinni sobie uświadomić zarówno własne prawo do kultury, jak i obowiązek pracy nad sobą w tej dziedzinie. Zadaniem chrześcijan jest przepojenie każdorazowej kultury „duchem” chrześcijaństwa, a staje się ona chrześcijańska wówczas, kiedy uwzględnia objawione przez Boga prawdy, idee i wartości, zamieniając je w czyn, co jest procesem, który nigdy się nie kończy ${ }^{73}$.

Samo przebywanie i kontakt z innymi kulturami nie wprowadza automatycznie postawy szacunku i otwartości na innych. Z drugiej strony poszukiwanie wielokulturowości też nie jest celem samym w sobie, gdyż Ewangelia zaprasza nas do inkulturacji, która jest czymś więcej niż tylko kontaktowaniem się z innymi kulturami ${ }^{74}$. Inkulturacja wyraża jeden $\mathrm{z}$ elementów wielkiej tajemnicy wcielenia i ma za zadanie wszczepienie siły Ewangelii w samą istotę kultury i jej zasadnicze elementy, czyli powinna szanować wartości i bogactwa innych kultur. W ten sposób inkulturacja „będzie mogła doprowadzić ludzi o różnych formach kultury do poznania ukrytej tajemnicy i dopomóc im w wydobywaniu z ich własnej żywej tradycji (semina verbi) oryginalnych znaczeń chrześcijańskiego życia, sprawowania liturgii i sposobu myślenia"75. Inkulturacja dzięki tajemnicy wcielenia odgrywa zasadniczą rolę w ewangelizacji misyjnej i ma prowadzić do zakorzenienia się przekazu wiary w kulturze lokalnej $^{76}$, do przenikania Dobrej Nowiny o zbawieniu w żywą tkankę kultury ${ }^{77}$.

Głoszenia Ewangelii nie można utożsamić z kulturą, ale jest możliwe nawiązanie z nią takiego kontaktu, który poprzez bogactwo form kulturowych pozwoli na wyrażenie wiary. Dlatego na koniec tych rozważań warto przytoczyć jedną z sentencji Jana Pawła II, głoszącą, że „wiara, która nie staje się kulturą, jest wiarą, która nie została w pełni zaakceptowaną, nie przemyślaną dogłębnie, nie przeżywaną z wiernością"78.

${ }^{72}$ Por. Z. Zdybicka, Jaka kultura?, dz. cyt., s. 377.

${ }^{73}$ Por. F. König, K. Waldenfels, Kultura/Kultury, dz. cyt., s. 211.

${ }^{74}$ Por. C. Ezeam, Formation multiculturelle, dz. cyt., s. 39.

${ }^{75}$ Jan Paweł II, Catechesi tradendae, nr 53.

${ }^{76}$ Por. J. Górski, Nowy paradygmat misji, Warszawa 2006, s. 36.

77 Por. S. Budzik, Człowiek zdezorientowany, w: W trosce o kulturę, red. B. Bejze, Warszawa 1996, s. 63.

${ }^{78}$ A.R. Crollius, Inkulturacja, dz. cyt., s. 127. 


\section{THE IMPORTANCE OF CULTURE IN THE PROCESS OF EVANGELIZATION}

\section{SUMMARY}

The article focuses on the concept of culture, its etymology, various anthropological interpretations and the way in which the Catholic Church has historically understood the reality of culture. The analysis of evolution of such an understanding culminates in evaluation of the contributions of the $2^{\text {nd }}$ Vatican Council and the consequences of this development for the missionary involvement of the Church. While the Church is historically related to concrete cultural contexts, the Gospel is not limited to any of those contexts. The main challenge of the missionary work is to set up fruitful relations with the local cultures in order to establish mutual relations between the Gospel and cultural values.

Keywords: culture, Gospel, Church, encounter, culture and missions, faith in Christ

Słowa kluczowe: kultura, Ewangelia, Kościół, spotkanie, kultura i misje, wiara w Chrystusa

\section{BIBLIOGRAFIA}

Bartnik C.S., Personalizm, Lublin 2000.

Bartnik C.S., Teologia kultury, Lublin 1999.

Bevans S.B., Schroeder R.P., Constants in Context. A Theology of Mission for Today, New York 2004.

Breviarium missionum. Wybór dokumentów Kościoła dotyczących dzieła misyjnego, t. 1, red. B. Wodecki, F. Wodecki, F. Zapłata, Warszawa 1979.

Budzik S., Człowiek zdezorientowany, w: W trosce o kulturę, red. B. Bejze, Warszawa 1996, s. 59-64 .

Burszta W., Różnorodność i tożsamość. Antropologia jako kulturowa refleksyjność, Poznań 2004.

Crollius A.R., Inkulturacja, w: Kościót misyjny, red. S. Karotempler, tłum. R. Dziura, A. Halemba, Warszawa 1997, s. 125-134.

Ezeam C., Formation multiculturelle, „Spiritus” 190 (2008), s. 37-49.

Górski J., Nowy paradygmat misji, Warszawa 2006.

http://pl.wikipedia.org/wiki/Kultura, [dostęp 20.10.2014].

Jan Paweł II, Catechesi tradendae, w: Jan Pawet II Encykliki i adhortacje 1979-1981, red. J. Sobiepan, Warszawa1983, s. 161-219.

Jan Paweł II, Fides et ratio, Kraków 1998.

Jan Paweł II, Redemptoris missio, w: Encykliki Ojca Świętego Jana Pawła II, t. I, Kraków 1996, s. 377-460.

Jan Paweł II, Redemptor hominis, w: Encykliki Ojca Świętego Jana Pawła II, t. I, Kraków 1996, s. 3-53.

Jaszczuk R., Ewangelizacja kultur i inkulturacja Ewangelii, Warszawa 2012. 
Kasprzak S., Organizacja działalności misyjnej Kościoła w świetle prawa kanonicznego, Lublin 1999.

Kawecki W., Kościót i kultura w dialogu, Kraków 2008.

Kłosowska A., Kultura, w: Encyklopedia kultury polskiej XX wieku. Pojęcia i problemy wiedzy o kulturze, red. A. Kłosowska, Wrocław 1991, s. 17-50.

König F., Waldenfels K., Kultura/Kultury, w: F. König, K. Waldenfels, Leksykon religii, Warszawa 1997, s. 209-212.

Kroeber A.L., Istota kultury, Warszawa 2002.

Leon XIII, Rerum novarum, w: Dokumenty nauki społecznej Kościoła, red. M. Radwan, L. Dyczewski, A. Stanowski, Rzym-Lublin 1987, s. 41-65.

Luzbetak L.J., Kościół a kultury. Nowe perspektywy w antropologii misyjnej, tłum. S. Kotarski, Warszawa 1998.

Miotk A., Aż na krańce ziemi. Popularna historia misji, Warszawa 2005.

Olbrycht K., Godność osoby źródtem i wartościa kultury chrześcijańskiej Europy, w: Osobowy wymiar kultury, red. J. Dobrzyńska, Warszawa 2004, s. 15-28.

Paweł VI, Evangelii nuntiandi, w: Misje po Soborze Watykańskim II, red. W. Kowalak, K. Rybacka, B. Skóra, F. Zapłata, Płock 1981, s. 257-291.

Pietrzak A., Uzasadnienie inkulturacji we wspótczesnej teologii, „Roczniki Teologiczne” 54 (2007), z. 9, s. 5-21.

Sakowicz E., Kręgi kulturowe i religijne, „Misje Dzisiaj” 6 (2010), s. 6-7.

Sobór Watykański II, Dekret o misyjnej działalności Kościoła Ad gentes, Poznań 2002.

Sobór Watykański II, Konstytucja dogmatyczna o Kościele Lumen gentium, Poznań 2002.

Sobór Watykański II, Konstytucja duszpasterska o Kościele w świecie współczesnym Gaudium et spes, Poznań 2002.

Wojtyła K., Rozważania o istocie człowieka, Kraków 1999.

Zdybicka Z., Człowiek i religia, Lublin 1977.

Zdybicka Z., Jaka kultura?, w: W trosce o kulturę, red. B. Bejze, Warszawa 1996, s. 375-380.

S. ANNA MIŚKOWIEC FMM - w 1991 r. ukończyła studia magistersko-licencjackie z misjologii w Akademii Teologii Katolickiej w Warszawie. W latach 1999-2004 pracownik Centrali Krajowej Papieskich Dzieł Misyjnych w Warszawie i członek zespołu redakcyjnego dwumiesięcznika „Misje Dzisiaj”. Obecnie doktorantka w Instytucie Teologii Fundamentalnej KUL. Jest członkiem Krajowej Rady Misyjnej przy Komisji Episkopatu Polski do Spraw Misji. Opublikowała niedawno Kapłaństwo $w$ państwie Inków, w: Kapłaństwo $w$ religiach świata, red. W. Cisło, J. Różański, Warszawa 2013, s. 209-228, a także Międzynarodowość charyzmatu Franciszkanek Misjonarek Maryi, „Collectanea Theologica” 84 (2014) nr 2, s. 157-165. 